光通信用長波長帯面発光レーザーの研究開発の現状

\author{
近藤 正彦 \\ RWCP光インターコネクション日立研究室 (テ185-8601 東京都国分寺市東恋ヶ筀1-280)
}

\title{
Present State of Long-Wavelength Vertical-Cavity Surface-Emitting Lasers
}

\author{
Masahiko KONDOW \\ RWCP Optoelectronics Hitachi Laboratory, clo Central Research Laboratory, Hitachi, Ltd., \\ 1-280 Higashi-Koigakubo, Kokubunji, Tokyo 185-8601
}

(Received June 18, 2001)

\begin{abstract}
Long-wavelength vertical-cavity surface-emitting lasers (VCSELs) are required as light sources for next-generation optical communications. In this review, technical issues concerning fabrication of long-wavelength VCSELs are discussed, and approaches to make a breakthrough regarding these issues are presented.
\end{abstract}

Key Words: Long-wavelength, Vertical-cavity surface-emitting laser (VCSEL), Optical communications

\section{1.まえがき}

面発光レーザー, VCSEL(Vertical-Cavity Surface-Emitting Laserの略でビクセルと読む。),ともに音の響きが良く,研 究者のロマンをかき立てる。しかし, 実際のビジネスでは, そうそう甘いことを言わせてくれない. 半導体レーザー の主市場のひとつである光ファイバ通信では,市場の黎明 期から端面発光型レーザーが使用されてきた．従って, 面 発光レーザーが世に出るためには, 先行する端面発光型 レーザーに取って代われなければならない，面発光レー ザーは, 本小特集の他の解説論文などに記載されているよ うに, 従来の端面発光型レーザーにはない多くの利点(およ び多少の欠点)を持っており，優れたレーザー構造である. しかし, 利点の多くはシステムの低価格化に結び付くもの であり,端面発光型レーザーに無かった機能を実現するも のは未だ少ない.一般に, 工業製品は大量生産することで コストが下がり生産性が向上する。逆に言えば,生産技術 の立ち上がり時に低価格化を実現することは難しい。 従って, 低価格を売りにして市場に挑む面発光レーザーに とって,技術開発および生産設備への投資を市場のニーズ とタイミングを整合させて,生産技術の立ち上がりを如何 にスムーズに行うかが非常に重要である。

現在市販されている面発光レーザーは,作製の容易さ(実 際には困難さの少なさ)からレーザー波長が, $850 \mathrm{~nm} も し く$ は980nmに限定されている。この波長帯では, 高速・長距 離伝送に適合するシングルモードファイバが利用できず, マルチモードファイバを使用せざるを得ない. そこで, 面 発光レーザーのデビュー市場は, 従来の長距離光ファイバ 通信市場ではなく,それほど高速および長距離伝送特性が
必要とされない光LAN(Local Area Network)になった．光 ファイバ通信の市場は, 数は出ないが単価の高い幹線系, 数 は出るが単価の低いアクセス系, その中間のメトロ系と, 伝 送距離により住み分けされている. 光LANは,アクセス系 よりも更に下の最ローエンドの市場である。（尚, 階層の上 下関係と市場の大きさとは, 全く無関係である。)低価格を 売りにする面発光レーザーとシステム価格の低さが非常 に重要なLAN市場は, よく合致した。実際, 90年代後半か らのインターネットブームにも乗り, 面発光レーザーはギ ガビットイーサ(1000BASE-SX)なじのLAN市埸を得るこ とに成功した。ところが, 最近電気接続(1000BASE-T)でも ギガビットイーサに対応できるようになってきた．面発 光レーザーは, 低価格の利点が失われつつあるばかりでな なく, より低価格化に適する電気接続に反対に市場を奪わ れつつある。ギガビットイーサにおける光接続と電気接 続の大きな特性の違いは, 伝送距離である。1000BASE-SX 及び100BASE-T規格の最大延長距離は, それぞれ, $500 \mathrm{~m}$ と 100mである.100mあれば室内の配線には十分対応できる が, 500mでは階が異なる部屋や建物間の接続には不充分な 場合が多い. 従って, 500mと云う距離は,「带に短し, タス キに長し」で中途半端である.

面発光レーザーが次なる市場を得るためには, 電気接続 では実現できない光接続ならではの高速伝送特性を売り にする必要がある。現在, LANの高速化が進み, 必要とさ れる最高伝送速度は $1 \mathrm{~Gb} / \mathrm{s}$ から $10 \mathrm{~Gb} / \mathrm{s}$ へ移行しょうとして いる．従って, 新たな市場が必要な面発光レーザーにとっ ては, 追い風と言える。この場合, 要求される伝送距離は, 望ましくは $10 \mathrm{~km}$, 最低でも $2-3 \mathrm{~km}$ である. $10 \mathrm{~Gb} / \mathrm{s} \cdot 10 \mathrm{~km}$ の 仕様は,まさにアクセス系光ファイバ通信と同じである. 
従って,デビュー時には避けた従来型の端面発光型レー ザーとの勝負となる。（次期市場は, $10 \mathrm{~Gb} / \mathrm{s}$ と超高速なので 伝送距離は数 $100 \mathrm{~m}$ でも良いとの意見もあるが,伝送距離が 長いほど早く高速性が要求され市場が先に立ち上がるの で10kmは死守すべきであろう。)

現在の面発光レーザーシステムの伝送特性が良くない 理由は, 上述したように波長带が異なるため高性能なシン グルモードファイバを使用できないからである。決して 素子そのもの特性が不十分なためではない. 面発光レー ザーシステムの伝送特性を改善するには2つのアプローチ がある。1つは,レーザーの波長带を現在のままとし, 使用 できるファイバの特性を改善する。もう1つは, 既存のシン グルモードファイバを使用できるように,レーザーの波長 を $1.3 \mu \mathrm{m}$ 帯もしくは $1.55 \mu \mathrm{m}$ 帯へ移す.

第1のアプローチに関しては, 最近 $10 \mathrm{~Gb} / \mathrm{s} て ゙ 1.6 \mathrm{~km}$ の距離 を伝送する事が出来る新構造のマルチモードファイバが 研究室レベルで開発された1). しかし, ファイバの内部構 造が複雑で, 高価格になりそうである。LAN応用と言えど も,数キロの伝送距離ではファイバのコストは無視できな い.しかし,量産技術がひとたび完成されれば問題がなく なり,本命技術になる可能性も十分高い.

第2のアプローチは, 正攻法である。また, 面発光レー ザーが先行する端面発光型レーザーに取って代わって主 流になるためには避けてはならない道でもある。一方, 現 在までの多くの努力にもかかわらず未だに長波長面発光 レーザーが実用化できていないのは,技術的に大変困難な ことの裏返しでもある。また, 繰り返しになるが, 低価格 を売りにして市場に挑む面発光レーザーにとって, 技術開 発を市場のニーズに整合できるかどうかが生死を決め 万. 数年後には 10 ギガビットイーサー市場が木格的に立 ち上がる状勢にある。長波長面発光レーザーの開発は,端 面発光型レーザの低価格化挔よび上記第1のアプローチと のレースとなり,時間的余裕があまりない。現在, その実 現を目指して幾つかのアプローチが試みられている。こ こ数年の進展を全般的にみるとなんとかなりそうな状況 であるが,このアプローチが当確だと言えるにはまだ至っ ていない.しかし, 逆に考元ると, 複数のアプローチが競 合している現状には望みがあるのかもしれない。

本論文では, 結晶材料の観点から, 長波長面発光レーザー が何故困難なのか説明し，六れを打破するために現在試み られているアプローチを紹介する，最後に，ポスト10ギガ

\section{Edge-emitting laser}

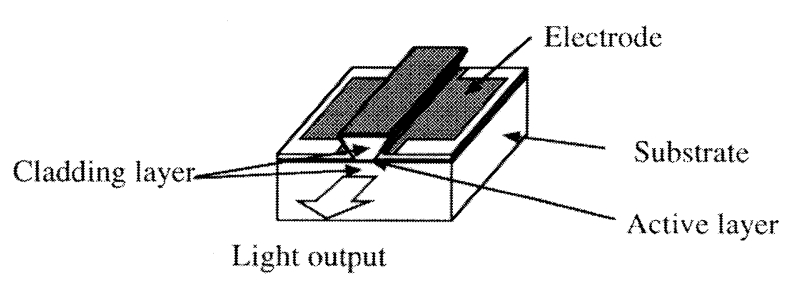

ビットイーサーについて述べる.

\section{2. 長波長帯面発光レーザーが難しい理由}

Fig.1に, 従来の端面発光型レーザー (Edge-emitting laser) と面発光レーザー (VCSEL) の構造概念図を示す。端面発 光型レーザーでは, 基板結晶 (Substrate)の上方に光を出す 活性層 (Active layer)がエピタキシャル成長により作製され ている.そして, 活性層の上下には, 光とキャリア(電子と 正孔）を活性層内に効率良く閉じ込めるためのクラッド層 (Cladding layer)が配置されている。また, 1 対の端面(へき 開面)が反射鏡となり,レーザー発振を得るための共振器が 形成される. 従って,レーザー光は基板結晶と平行に出射 される. 長波長带端面発光型レーザーを構成する結晶材 料に求められる主な条件は, 活性層が $1.3 \mu \mathrm{m}$ もくは $1.55 \mu \mathrm{m}$ 带で発光する事, クラッド層のバンドギャップが活 性層より $0.3 \mathrm{eV}$ 程度大きい事, そして, 活性層とクラッド層 が基板結晶上にエピタキシャル成長できる事の3つであ る.

面発光レーザーでも, 基板結晶の上方に光を出す活性層 がエピタキシャル成長されている，大きな違いは, 活性層 の上下に屈折率が異なる材料を交互に積層した多層膜反 射鏡 (DBR: Distributed Bragg Reflector)が配置されているこ とである. 上下の多層膜反射鏡の間が, 共振器となる。一 般に, 面発光レーザーでは実効的な共振器長が半導体中で のレーザー波長と同程度と非常に短い。その場合, 多層膜 反射鏡がクラッド層の役割も果たすので,クラッド層を別 に設けない場合が多い.レーザ一光は, 多層膜反射鏡と垂 直, 即ち, 基板結晶と垂直な方向に出射される. 面発光レ一 ザーでは, レーザー光が共振器間を往復する際に発振に必 要な利得が得られる距離はわずかに活性層の厚みのみで ある. 因って,光の損失を極力押さえなければレーザー発 振を実現できない，そのため，多層膜反射鏡の反射率を 99.5\%以上と極めて高くしなければならない. 多層膜反射 鏡を構成する材料の屈折率差が大きい場合, 比較的少ない 積層ペア数で必要な反射率を実現できる. しかし, 屈折率 差が小さい場合, 多層膜の積層ぺア数を大幅に増やさなけ ればならない。必要な積層ペア数が 20 対から 30 対程度ま でなら技術的に対応可能であるが, 50対以上になると作製 誤差などが原因して積層ペア数をいくら増やしても必要 な反射率を得ることができなくなる。長波長帯面発光
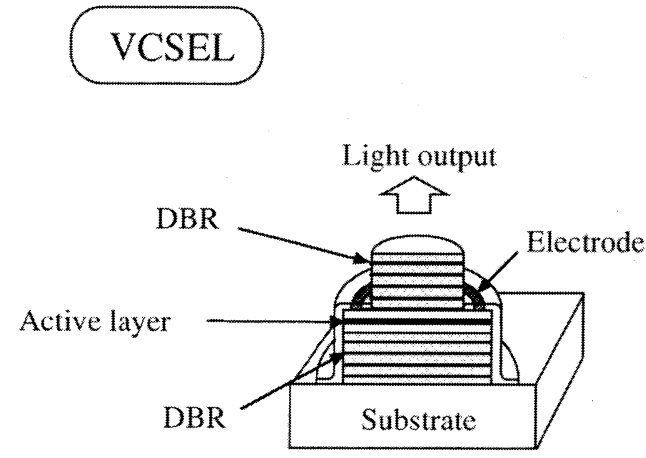

Fig.1 Schematic structures of an Edge-emitting laser and a VCSEL. 
レーザーにおいて材料的に求められる主もな条件は, 活性 層が $1.3 \mu \mathrm{m}$ もしは $1.55 \mu \mathrm{m}$ 带で発光する事, 多層膜反射鏡 を構成する材料のバンドギャップ差が $1 \mathrm{eV}$ 以上, 最低でも $0.5 \mathrm{eV}$ 以上大きい事(おおざっぱに言って屈折率はバンド ギャップに反比例する．以下での議論のためにここでは バンドギャップを用いて条件を記述する。), そして, 活性 層と多層膜反射鏡が基板結晶上にエピタキシャル成長で きる事の3つである．多層膜反射鏡はレーザー光を吸収し てはならないので, 多層膜反射鏡の高屈折率 (低バンド ギャップ)材料のバンドギャップは活性層のバンドギャッ プよりも大きくなければならない.多層膜反射鏡の高屈 折率材料と活性層とのバンドギャップ差は $0.1 \mathrm{eV}$ 程度必要 なので, 上記の第 2 条件は, 多層膜反射鏡の低屈折率 (高 バンドギャップ)材料のバンドギャップが活性層よりも $1.1 \mathrm{eV}$ 以上, 最低でも0.6eV以上大きい事, と言い変えても良 い. 尚, 多層膜反射鏡のうち活性層より上部のものは, 必 ずしも半導体である必要は無く $\mathrm{SiO}_{2} や \mathrm{TiO}_{2}$ 等の誘電体材料 を使用しても良い。しかし,下部多層膜反射鏡はその上部 に活性層をエピタキシャル成長させなくてはならないの で, 上記第3の条件は緩まない（下部多層膜反射鏡にも誘 電体材料を使用するアプローチもあるが2), あまり有望と は言いがたく現在は殆ど行われていない， )

以上の端面発光型レーザーと面発光レーザーに必要な 条件の違いを整理すると, 端面発光型レーザーでは活性層 よりもバンドギャップが $0.3 \mathrm{eV}$ 程度大きい材料で良いが, 面 発光レーザーでは $1.1 \mathrm{eV}$ 以上, 最低でも $0.6 \mathrm{eV}$ 以上大きい材 料をエピタキシャル成長させなければならない事にな る. Fig.2に, III-V族化合物半導体の格子定数とバンド ギャップの関係を示す．網掛けを施した従来材料に注目 して頂きたい. 全般的に, 格子定数が大きくなる程, バン ドギャップが小さくなる.エピタキシャル成長を行うに は, 基板結唱が必要である。現在, 量産されているIII-V族
基板結晶は, GaP, GaAs, 及びInPだけである。エピタキシャ ル成長では, エピ層の格子定数を基板結晶に整合させなけ ればならない. 従って, エピタキシャル成長できる材料は, 同図で縦方向に延びる点線の上またはその近傍(層厚が薄 ければ, 点線から多少離れていても成長可能である。）に限 定される. $1.3 \mu \mathrm{m} も し く は 1.55 \mu \mathrm{m}$ の長波長帯材料は,バン ドギャップの值が 0.95 から $0.8 \mathrm{eV}$ 範囲になければならな い. $\mathrm{GaP}$ 及び $\mathrm{GaAs}$ と格子整合する点線上では対応する材 料が存在せず, 長波長带を実現できるのはInP基板上に限ら れる。

長波長面発光レーザー作製の難しさを説明する前に, 既 存の850および980nm帯面発光レーザーで使われている材 料について述べる。基板結晶には, GaAsが使用される。 $850 \mathrm{~nm}$ 帯 $(1.45 \mathrm{eV})$ および980nm帯 $(1.27 \mathrm{eV})$ の活性層には,そ れぞれ, GaAsまたはGaAsに少量のInを加えたGaInAsが用 いられている. 850および980nm帯の多層膜反射鏡には, そ れぞれ, AlAsとGaAsに少量のAlを加えたAlGaAs, 及び, AlAsとGaAsが使用される. AlAsおよびAlGaAsは, GaAsと ほぼ格子整合するのでGaAs上にエピタキシャル成長でき

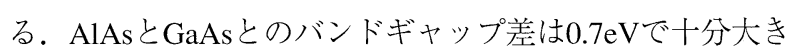
いとは言いがたいが,多層膜反射鏡に必要な積層ぺア数は 25 対程度で技術的に対応できる. AlAsは2元化合物半導体 であり, 3元, 4 元の混晶半導体に比べると結晶成長が遥か に易しい.（従って，生産性が高く低価格化に向いてい る.)また, 2 元化合物半導体のAlAsは, 3 元, 4 元の混晶半導 体に比べると熱抵抗が1桁程度低い利点も有している.さ らに, $\mathrm{AlAs}$ は高温の水蒸気中で酸化すると絶縁体の $\mathrm{AlO}_{\mathrm{x}}$ に なるので, 電流狭窄構造などの素子構造作製においても, 強 い利点を有している.

次に, 長波長面発光レーザーの難しさを説明する. InP基 板上に成長できる材料で,バンドギャップが最大のものは, $\mathrm{AlPSb}$ と1AsSbである。それらのバンドギャップは $1.8 \mathrm{eV}$

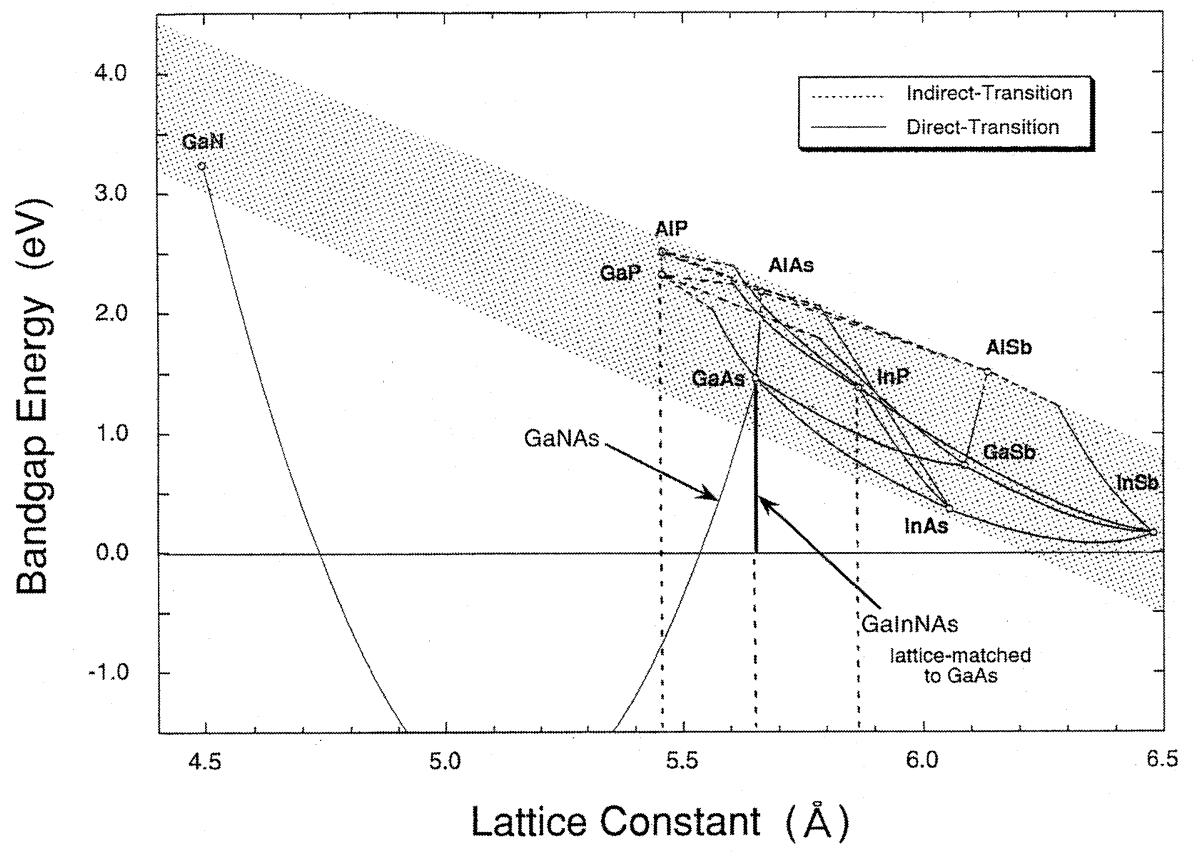

Fig.2 Bandgap Energy vs. Lattice Constant in III-V alloy semiconductors. 
なので, 活性層と十分なバンドギャップ差を有する。しか し,残念なことに, $\mathrm{Sb}$ (アンチモン)を含む材料の結晶成長 は非常に難しく,現在まで商用化されている発光素子はな い.(ここ数年の結晶成長技術の進展により,かなり良質な ものが得られるようになってきており将来性はある。)次 にバンドギャップが大きいものは, AlInAsである。そのバ ンドギャップは $1.5 \mathrm{eV}$ なの゙, 活性層の発光波長が $1.55 \mu \mathrm{m}$ 带 $(0.8 \mathrm{eV})$ なら,かろうじて必要なバンドギャップ差を得る ことができる。一方, $1.3 \mu \mathrm{m}$ 带 $(0.95 \mathrm{eV})$ では非常に苦しい.

$1.55 \mu \mathrm{m}$ 帯の活性層とAlInAs/AlGaInAs多層膜反射鏡の組み 合わせで,なんとか必要な反射率を得ることができるが多 層膜反射鏡に必要な積層ぺア数は 35 対程度にもなる。そ のため,多層膜反射鏡, 特にp型の伝導型を有する多層膜反 射鏡の熱抵抗と電気抵抗が非常に大きくなる．InP基板上 に形成される $1.3 \mu \mathrm{m}$ 及び $1.55 \mu \mathrm{m}$ 帯の活性層では, 材料に GaInAsPが使用される。しかし, GaInAsP活性層は物性的な 理由により高温での動作に難点がある。従って, $1.55 \mu \mathrm{m}$ 帯 のGaInAsP活性層とAIInAs多層膜反射鏡の組み合わせでは, 高温での動作自体が極めて難しくなる。(LAN系抢よびア クセス系光ファイバ通信システムでは, 価格を下げるため にレーザーの温調装置を省かなければならない，PC内や 屋外にも置かれる光伝送モジュールでは最高 $85^{\circ} \mathrm{C}$ までの 環境温度を想定する必要があり,レーザーはその温度でも 伝送に十分な特性を有する必要がある。）以上の理由によ り,長波長面発光レーザーを実現するのは極めて難しい。

ここで, 面発光レーザーに打ける長波長化による利点に ついて言及しておく、仮に長波長带面発光レーザーの素 子抵抗が既存の $850 \mathrm{~nm}$ および980nm带面発光レーザーと同

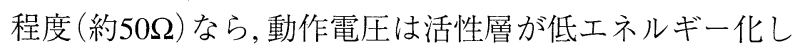
た分だけ下がる。すなわち, $1.55 \mu \mathrm{m}$ 帯では, $850 \mathrm{~nm}$ 帯から $0.5 \mathrm{~V}$ 以上の動作電圧の低下が期待できる。レーザーの動 作電圧低減に対するシステム要求は非常に強いので, 長波 長面発光レーザーはこの点で非常に有利である。もう1つ の利点は, 高出力化の可能性である. 面発光レーザーの活 性領域の体積は非常に小さいので, 低しきい電流や超高速 動作を実現できるが, 同時に活性領域から取り出せる光出 力が制限されてしまう。（伝送速度が上がれば1ビットあ たりの時間が短くなる。受光素子に同量の光子数を与え るためには,レーザーの光出力を上げなければならない. 因って, 高速伝送時にはレーザーに高出力特性が要求され る。)既存の $850 \mathrm{~nm}$ 扩よび $980 \mathrm{~nm}$ 帯面発光レーザーにおい て単一横モード動作が得られる活性領域の最大直径は2か ら3 3 mであるが, この最大直径はレーザー波長に比例して 増加すると予想される。活性領域の体積は半径の 2 乗に比 例して増加するので, 長波長面発光レーザーの基本特性を 既存の850nm扔よび980 nm帯面発光レーザーと同様まで改 善することができれば, 活性領域の体積増大に応じて高出 力化も可能である。 まだ初期的実験ではあるが, $1.3 \mu \mathrm{m}$ 帯 で $8 \mu \mathrm{m}^{3)}, 1.55 \mu \mathrm{m}$ 帯で $\left.12 \mu \mathrm{m}^{4}\right)$ まで活性領域の直径を広げて も単一横モード動作が得られたとの報告がある。これら の值は予想よりもかなり大きく今後の検証が必要である が, 長波長化により単一横モードが得られる活性領域の最 大直径が増加することは間違いなさそうである。

\section{3. 長波長面発光レーザーへのアプローチ}

個々のアプローチを説明する前に, $1.3 \mu \mathrm{m}$ 帯と $1.55 \mu \mathrm{m}$ 帯 のどちらが相応しいか議論しておく. 石英材料を用いた 通常分散ファイバは波長が1.31 $\mu$ m近傍で屈折率の波長分 散值が最小となり,長距離伝送しても光パルスの時間波形 が劣化しない. 但し, 光ファイバの損失は $1.55 \mu \mathrm{m}$ 帯よりも 大きい. $1.55 \mu \mathrm{m}$ 帯の光ファイバの特徴は, その逆で, 損失 は小さいが波長分散がある. $1.55 \mu \mathrm{m}$ 帯の光ファイバの波 長分散は, 分散補償ファイバを使用すれば無くすることが できる。しかし, 分散補償ファイバを用いると, その分価 格が高くなる. 端面発光型レーザーを使用する現在の光 ファイバ通信の市場では, 長距離伝送が必要な幹線系では $1.55 \mu \mathrm{m}$ 带, システム価格の低さが重要なアクセス系では $1.3 \mu \mathrm{m}$ 帯となっている. 面発光レーザーが, 将来端面発光 型レーザーの牙城である幹線系の市場を狙うには $1.55 \mu \mathrm{m}$ 帯でなければならない.しかし, 次期市場のアクセス系で は, 低価格化の観点から $1.3 \mu \mathrm{m}$ 带が好ましいと言える。（長 波長面発光レーザーが実用化に至っていない現状では, 選 り好みは言えないが...)以下に, 各アプローチの詳細を説 明する。

\section{A. 直接接着法5)}

本法では, GaInAsP活性層を InP 基板上に, $\mathrm{AlAs} / \mathrm{GaAs}$ 多層 膜反射鏡をGaAs基板上に別々にエピタキシャル成長させ, それらを高温で圧着して一体化させる。エピタキシャル 成長の概念をやぶる画期的方法である. $1.3 \mu \mathrm{m}$ 帯と $1.55 \mu \mathrm{m}$ 带のどららにも適応可能である. 接着界面も原子的以繋 がり,なかなか良好である。しかし, 複数の基板結晶が必 要なので低価格化において有利とは言えない.GaAs基板 は6インチまでのものが市販されているが, InP基板は3イン チまでしかなく, 直接接着法では大口径GaAs基板の利点を 生かせない。また, 接着界面はへテロ接合となるので接触 電圧が発生し動作電圧が高くなる。この点に関しては, 直 接接着法で作製した長波長面発光レーザーと850nmまたは 980 nm 帯面発光レーザーを更に一体化し, 長波長面発光 レーザーを光励起することで接着界面に電流を流さない 回避方法もある6). 実際,この方法で作製された長波長面 発光レーザーが既に市販されている。問題点は, 活性層が 元々高温動作に難点があるGaInAsPであり, 素子構造も複 雑なため熱放出が悪く高温特性が徳いことである。また, GaInAsP活性層の光学利得はあまり高くなく, 高速動作に 難点がある。他には, 一般に大面積基板では均一な直接接 着が難しく, 量産性が懸念されるが, 歩留まり率などは明 らかになっていない.

\section{B.トンネル接合を利用する方法7,8}

前章で述べたように, 従来材料を用いて $1.55 \mu \mathrm{m}$ 帯長波長 面発光レーザーを作製する場合の問題は, $\mathrm{p}$ 型多層膜反射鏡 の熱抵抗と電気抵抗が大きい事である. 逆に考えれば, $\mathrm{p}$ 型 多層膜反射鏡を使用しなければ問題が解決される可能性 がある。トンネル接合は, $1 \times 10^{20} \mathrm{~cm}^{-3}$ 程度と極めて高濃度 にドーピングした $\mathrm{p}$ 型とn型の半導体の接合であり,低抵抗 
かつ低電圧損で $\mathrm{p}$ 型半導体と $\mathrm{n}$ 型半導体を接合することが できる. $\mathrm{n}$ 型の基板結晶上に $\mathrm{n}$ 型多層膜反射鏡, 活性層, $\mathrm{p}$ 型 のクラッド層, そして, トンネル接合を形成すれば, その上 にはn型多層膜反射鏡を作製すれば良い. 従って, p型多層 膜反射鏡を作製する必要がなくなる，実際，トンネル接合 を利用した $1.55 \mu \mathrm{m}$ 帯長波長面発光レーザーは高温でも比 較的良好な素子特性を示している9). 因って,トンネル接 合は長波長面発光レーザーを実現する有力なアプローチ と見なされている。 今後の課題は, 以下のとおり。トンネ ル接合を作製する際の超高濃度ドーピングでは, 材料や成 長方法が制限される。AlAsを酸化させて電流狭窄を作製 する技術が利用できないので素子構造作製が複雑にな る. InP基板を使用するので, 大口径でかつ安価な GaAs基 板と比べると低価格化で不利. 多層膜反射鏡に 3 元もしく は4元の混晶半導体を使用するので, 結晶成長に非常に高度 な再現性, 面内均一性が要求される。(AlAs/GaAs多層膜反 射鏡を作製するだけでも技術的には非常に難しい，混晶 半導体を用いた多層膜反射鏡が量産できるかどうかは今 後の大きな課題である。）

トンネル接合を利用するアプローチは, 歴史的経緯から $1.55 \mu \mathrm{m}$ 带長波長面発光レーザーの場合が多いが, 後述する 材料と組み合わせれば, $1.3 \mu \mathrm{m}$ 帯長波長面発光レーザーで も適応可能であり, 発展性が期待できる.

C. GaInAs3元混晶半導体を基板結晶に利用する方法 ${ }^{10)}$ 前章で示した問題点は, 使用できる基板結晶がInPしかな い事に由来している，仮に, $\mathrm{GaAs}$ と InPの中間の格子定数 を有する基板結晶があったなら,すべての問題は解決され るであろう。そこで, GaInAs3元混晶半導体を基板結晶に 利用するアプローチがある。実際, 研究室レベルでは GaInAs3元基板が作製されており，その上に作製した端面 発光型レーザーの特性も良い. しかし, 混晶基板へのチャ レンジは長波長面発光レーザーよりも更に昔から試みら れており，量産化を達成するには極めて難しい技術であ る.

以下に, GaAs基板上にエピタキシャル成長可能な材料を 用いて活性層の波長を長波長化しょうとするアプローチ を4つ示す。

D. GaInAsを活性層に利用する方法11)

本法は, $0.98 \mu \mathrm{m}$ 帯面発光レーザーでも使われている GaInAs量子井戸層のIn組成を増やし, 発光波長を長波長化 する手法である．活性層に使われる量子井戸の厚みは, 一 般に $10 \mathrm{~nm}$ 以下と非常に薄い. 格子定数が基板結晶と多少 異なっても, 臨界歪 (これ以上格子歪が増えると転位が発生 して結晶性が急激に悪化する限界の格子歪量)に達するま ではエピタキシャル成長が可能である。実験の結果, $1.2 \mu \mathrm{m}$ 近傍で臨界歪に達する事が判った ${ }^{12)}$. 尚, 限界波長 直前まで素子特性の劣化はあまりない。レーザー波長が $1.2 \mu \mathrm{m}$ だと, $1.3 \mu \mathrm{m}$ 帯のシングルモードファイバが何とか使 える。但し, 現在の光ファイバ通信の規格からは外れる。 LAN用に新たな規格を作る事も可能だろうが, 今後の発展 性を考えると中途半端な妥協は躊躇される。他方, 以下に
示す3つの新材料と比べると結晶成長が格段に容易であり， 生産性が高い利点がある。

\section{E. GaAsSbを活性層に利用する方法13)}

Fig.2を見ると, GaAs とGaSbを結ぶGaAsSbはGaAsとInAs を結ぶGaInAsの曲線よりも上方にあり,長波長化に向かな い. しかし, ある成長条件で成長すると結晶内部に周期構 造が自然発生しバンドギャップが低エネルギー化するこ とが判った，成長条件を探る事で長波長化を実現する研 究が進められている。しかし, 丁度 $1.3 \mu \mathrm{m}$ 近傍で臨界歪に 達するらしく, 長波長化にはそれほど余裕がなさそうであ る14)。また, GaAsSb活性層はGaInAsPと同じく物性的な理 由で高温動作に難点がある。

\section{F. 量子ドットを活性層に利用する方法 ${ }^{15)}$}

$\mathrm{GaAs}$ 上に, 臨界歪を越える $(\mathrm{Ga})$ InAsを成長すると,テフ ロンフライパン上の水滴の様に凝縮して直径が数十 $\mathrm{nm}$ の ドット形状になる。こうして形成された量子ドットは, 発 生の極初期では結晶欠陥が無く, 発光材料として利用でき る.臨界歪を越えて In組成を増やすことが可能になるの で, 長波長化も可能である. 現状での課題は, ドットは自 然発生するので制御性が悪くあまり高密度に形成できな いことである，従って, 活性領域の体積を増やすことが難 しく,レーザー発振に十分な光学利得を得にくい. そのた め, 特に高温においてレーザーの特性が大きく劣化する. 量子ドットレーザーは, ドットの密度を如何に増やせるか に将来が託されている. 量子ドットレーザーは, 長波長化 以外でも従来の量子井戸レーザーにはない多くの利点が 期待できる。一方,物性的理由から高速動作特性に難があ り10Gb/s動作は難しいとの指摘もある16).

G. GaInNAsを活性層に利用する方法 ${ }^{17,18)}$

今まで説明してきたアプローチは全て従来材料を使用 しており,利用できる材料の制限から様々な困難に直面し ている。一方, 本アプローチのGaInNAsは著者によって作 られた新材料である. Fig.2においてGaAsより真下に延び る太線がGaInNAsである。 GaAsと格子整合でき, $1.3 \mu \mathrm{m}$ お よび $1.55 \mu \mathrm{m}$ のバンドギャップをカバーする。（実際にはIn 組成を大きく $N$ 組成を小さくして結晶成長するので, GaInNAsには圧縮の格子歪がかかっている）また, 深い量 子井戸を活性層に利用できるので高温特性に優れる。 よって, 長波長面発光レーザーを実現する理想的な材料と 考えられる. 新材料のGaInNAsで一番心配される点は, 素 子寿命である.しかし, 実験してみると大きな問題がない ことが判った ${ }^{19)}$. その他の問題点は, 結晶成長の手法やそ の条件が確立していないこと, 素子を設計する際に必須な 物性定数が不明なことである。しかし, 最近の研究により これらもかなり明らかになって来ている. その結果, 少な くとも $1.3 \mu \mathrm{m}$ 帯レーザーでは諸特性が実用化に十分なレベ ルに達している，米国のベンチャー企業Cielo社は, GaInNAs $1.3 \mu \mathrm{m}$ 帯面発光レーザーで $10 \mathrm{~Gb} / \mathrm{s} \cdot 10 \mathrm{~km}$ の伝送を実証し20), 2001年中の製品化を発表している. 従って, 本アプローチ が, 長波長面発光レーザーのブレークスルー技術として現 
在本命視されている。

4. ポスト10ギガビットイーサー

LAN市場は, 凡そ3-4年毎に,3倍の価格で10倍の伝送速度 を実現することを要求してくる．10Gb/sの後には，100 $\mathrm{Gb} / \mathrm{s}, 1 \mathrm{~Tb} / \mathrm{s}$ の伝送速度が必要になる。現状の半導体レー ザーの動作速度限界は, 数〜数 $10 \mathrm{~Gb} / \mathrm{s}$ なので, $100 \mathrm{~Gb} / \mathrm{s}$ 以上 の伝送速度を実現するためには複数のレーザーを使用し なければならないと予想される。面発光レーザーは, 原理 的に消費電力が小さくアレー化にも適しているので, 複数 のレーザーが必要なシステムに好適である。1Tb/sでは, 少 なくとも数十のレーザーを集積しなくてはならず,従来の 端面発光型レーザーでは実現が難しい。また,システム価 格を押さえるためには, 1 本の光ファイバで波長の異なる レーザー光を複数使用して伝送する波長多重法が必須に なる．面発光レーザーは, MEMS (Micro Electro-Mechanical Systems）との集積が容易なので, 共振器長を機械的に調節 することが可能であり, 波長可変に対応しやすい4)。従っ て,この点でも面発光レーザーは, 有利である．以上を鑑 みると, 10 年後には面発光レーザーが主流になる可能性が 十分ある。

\section{5. あとがき}

面発光レーザーやGaInNAsは日本で生まれた技術であ る.しかし,ビジネス的に成功しているのは欧米の企業で ある。これは,チャレンジすることが賞賛される社会と, maverickが許されない社会との違いによると思われる．尚， Maverick氏は, 所有する家畜に嫌がる焼印を押さなかった 心優しい人である．日本の社会は,米国の10-20年前を後追 いしており,10年後には日本の社会も変わっているかもし
れない. その頃に, 面発光レーザーと日本の社会・経済が どうなっているか楽しみである。

\section{参考文献}

1) R. Michalzik, G. Giaretta, A. J. Ritger, and Q. L. Williams: Proc. LEOS (1999) PD1.6.

2) T. Baba, Y. Yogo, K. Suzuki, F. Koyama, and K. Iga: Electron. Lett. 29 (1993) 913.

3) J. F. Klem, Kent D. Choquette, A. J. Fischer, O. Blum, A. A. Allerman, I. J. Fritz, S. R. Kurtz, W. G. Breiland, R. Sieg, and K. M. Geib: Proc. DRC (2000) PD.

4) D. Vakhshoori, P. D . Wang, M. Azimi, K. J. Knopp, and M. Jiang: Proc. OFC (2001) TuJ1-1.

5) J. J. Dudley, D. I. Babic, R. Mirin, L. Yang, B. I. Miller, R. J. Ram, T. Reynolds, E. L. Hu, and J. E. Bowers: Appl. Phys. Lett. 64 (1994) 1463.

6) V. Jayaraman, J. C. Geske, M. H. MqcDougal, F. H. Peters, T. D. Lowes, and T. T. Char: Proc. LEOS (1998) WI2.

7) Y. Kotaki, S. Uchiyama, and K. Iga: Ext. abst. 1984 SSDM, p. 133.

8) M. Ortsiefer, R. Shau, G. Bohm, F. Kohler, and M. C. Amann: Electron. Lett. 36 (2000) 437.

9) S. Nakagawa, E. Hall, G. Almuneau, J. K. Kim, D. A. Buell, H. Kroemer, and L. A. Coldren: Proc. LEOS (2000) ThF3.

10) H. Ishikawa: Appl. Phys. Lett. 63 (1993) 712.

11) D. Schlenker, T. Miyamoto, Z. Chen, F. Koyama, and K. Iga: IEEE Photon. Technol. Lett. 11 (1999) 946.

12) S. Sato and S. Satoh: Jpn. J. Appl. Phys. 38 (1999) L990.

13) T. Anan, K. Nishi, S. Sugou, K. Kasahara, M. Yamada, K. Tokutome, and A. Gomyo: Proc. LEOS (1997) PD1.4.

14) O. Blum and J. F. Klem: Proc. DRC (2000) p. 121

15) K. Mukai, N. Ohtsuka, M. Sugawara, and S. Yamazaki: J. Appl. Phys. 33 (1994) L1710.

16) D. G. Deppe, D. L. Huffaker, H. Huang, T. F. Boggess, and L. Zhang: Proc. LEOS (2000) TuV3.

17) M. Kondow, S. Nishimura, K. Shinoda, and K. Uomi: Japanese patent AP07-340520 (filed on 27 December 1995), US patent \#5912913 (registered on 15 June 1999).

18) K. Iga: Proc. IPRM (1996) ThA1-1.

19) M. Kondow, T. Kitatani, K. Nakahara, and T, Tanaka: Jpn. J. Appl. Phys. 38 (1999) L1355.

20) R. L. Naone, A. W. Jackson, S.A. Feld, D. Galt, K. J. Malone, and J. J. Hindi: Proc. CLEO (2001) CPD13-1.
長波長面発光レーザー (long-wavelength VCSEL)

長波長带の光を出す面発光レーザー．光ファイバの伝 播波長 $(1.3 \sim 1.55 \mu \mathrm{m})$ は, 最初に開発されたGaAs系半導体 レーザーの波長 $(0.85 \mu \mathrm{m})$ に比べて長いので長波長帯と呼 ばれている，長波長面発光レーザーは, 高性能で低コスト な光ファイバ通信用光源になる可能性が原理的に高いの
で, 市場から熱望されている。一方, 使用する材料の制限 から作製が難しい. 2001年現在, 長波長面発光レーザの本 格的な実用化に向けたブレークスルー技術が世界中で研 究開発されている。

(近藤 正彦) 